\title{
Distribution of metals and trace elements in adult and juvenile penguins from the Antarctic Peninsula area
}

\author{
Silvia Jerez • Miguel Motas • Jesús Benzal • Julia Diaz • \\ Virginia Vidal • Verónica D’Amico • Andrés Barbosa
}

\begin{abstract}
The presence of metals in the Antarctic environment is principally a natural phenomenon caused by geochemical characteristics of the region, although some anthropogenic activities can increase these natural levels. Antarctic penguins present several of the characteristics of useful sentinels of pollution in Antarctica such as they are long-lived species situated at the top of food web. The concentrations of $\mathrm{Al}, \mathrm{Cr}, \mathrm{Mn}, \mathrm{Fe}, \mathrm{Ni}, \mathrm{Cu}, \mathrm{Zn}, \mathrm{As}, \mathrm{Se}, \mathrm{Cd}$, and $\mathrm{Pb}$ were determined by inductively coupled plasmamass spectrometry in samples of liver, kidney, muscle, bone, feather, and stomach contents of gentoo, chinstrap, and Adélie penguin (12 adults, five juveniles) from carcasses of naturally dead individuals collected opportunistically in the Antarctic Peninsula area. The obtained results showed that accumulation and magnification of several elements can be occurring, so that $\mathrm{Cd}$ and Se reached levels potentially toxic in some specimens. The presence of human activities
\end{abstract}

S. Jerez $(\bowtie) \cdot$ M. Motas

Área de Toxicología, Facultad de Veterinaria,

Universidad de Murcia,

Campus de Espinardo,

30100 Murcia, Spain

e-mail: silviajerez@um.es

J. Benzal · A. Barbosa

Departamento de Ecología Funcional y Evolutiva,

Estación Experimental de Zonas Áridas, CSIC,

Carretera de Sacramento s/n, La Cañada de San Urbano,

04120 Almería, Spain

\section{J. Diaz}

Centro de Estudios Parasitológicos y de Vectores

(CCT La Plata-CONICET-UNLP),

No 584,

1900, La Plata, Argentina seems to be increasing the presence of toxic metals such as $\mathrm{Mn}, \mathrm{Cr}, \mathrm{Ni}$, or $\mathrm{Pb}$ in penguins.

Keywords Metals · Trace elements · Pollution · Antarctic penguins $\cdot$ Antarctic Peninsula

\section{Introduction}

The presence of metals in the Antarctic environment is a natural phenomenon caused by the geochemical characteristics of the different areas in Antarctica (Andrade et al. 2001; Sánchez-Hernández 2000), although several anthropogenic sources (oil spills, paints, open field garbage burning, or fuel combustion) contribute to increase these natural levels (Claridge et al. 1995; Curtosi et al. 2010; dos Santos et al. 2005; Poblet et al. 1997; Vodopivez and Curtosi 1998).
V. Vidal

Departamento de Sanidad Animal, Facultad de Veterinaria, Universidad de Murcia, Campus de Espinardo, 30100 Murcia, Spain

\section{D'Amico}

Centro Nacional Patagónico (CENPAT-CONICET), Boulevard Brown 2825,

Puerto Madryn, Chubut, Argentina

\author{
A. Barbosa \\ Departamento de Ecología Evolutiva, \\ Museo Nacional de Ciencias Naturales, CSIC, \\ C/ José Gutiérrez Abascal 2, \\ 28006 Madrid, Spain
}


Although the Protocol on Environmental Protection to the Antarctic Treaty (the Madrid Protocol of 1991) initiated a stage of regulation and control of the Antarctic activities, before its implementation many human activities were carried out without any consideration for the environmental health of this region (Curtosi et al. 2010). In addition, the recent human activity, such as research and an increase in tourism in the northern area of the Antarctic Peninsula (6,704 tourists and 59 voyages in 1992-1993 and 36,875 tourists and 239 voyages in 2009-2010, IAATO 2010) and its associated activities such as plane and ship trips, could have a significant effect on the accumulation of metals in the Antarctic biota. In this context, it has been observed that the levels of some trace metals are higher in Antarctic areas where an important human presence exists in comparison to more untouched areas (Jerez et al. 2011).

In this way, Antarctic seabirds may be useful indicators of regional environmental health, presenting several advantages for pollution monitoring in comparison to other organisms: They are top predators and long-lived species (biomagnification and bioaccumulation phenomena can occur), present wide distribution ranges with abundant populations, and integrate contamination over time and space (Burger and Gochfeld 2004; Walsh 1990). The main disadvantage in Antarctica is the difficulty to get large sample sizes as it is not allowed under the Antarctic Treaty to collect living individuals. Moreover, ethical standards recommend the use of non-invasive methods for sampling as an alternative to capture and sacrifice organisms. For this reason, several authors have used feathers, excreta, or eggs to study the abundance of metals and trace elements in Antarctic seabirds (e.g., Ancora et al. 2002; Bargagli et al. 1998; Jerez et al. 2011; Kureishy et al. 1993; Metcheva et al. 2006; Scheifler et al. 2005; Stewart et al. 1997; Sun and Xie 2001). However, valuable data on levels of these elements in internal tissues are still scarce (Bargagli et al. 1998; De Moreno et al. 1997; Honda et al. 1986; Norheim 1987; Nygard et al. 2001; Smichowski et al. 2006; Szefer et al. 1993a, b).

This study aims to increase the information on this issue investigating the concentrations of metals and trace elements in internal tissues and stomach contents of three species of Antarctic penguins (gentoo penguin-Pygoscelis papua, chinstrap penguin-Pygoscelis antarctica and Adélie penguin-Pygoscelis adeliae), identifying target organs for metal accumulation, studying the possible existence of biomagnification phenomena, and verifying if elevated or toxic levels are reached in penguin tissues.

\section{Materials and methods}

Penguin carcasses from naturally dead individuals (12 adults and five juveniles, see Table 1) were opportunistically collected
Table 1 Studied specimens

\begin{tabular}{|c|c|c|c|}
\hline Specie & Location & Age & Samples \\
\hline P. papua & King George Island & Adult & $\mathrm{L}, \mathrm{K}, \mathrm{M}, \mathrm{B}, \mathrm{SC}$ \\
\hline P. papua & King George Island & Adult & $\mathrm{L}, \mathrm{K}, \mathrm{M}, \mathrm{B}, \mathrm{F}, \mathrm{SC}$ \\
\hline P. рариа & King George Island & Adult & $\mathrm{L}, \mathrm{K}, \mathrm{M}, \mathrm{F}$ \\
\hline P. antarctica & King George Island & Adult & $\mathrm{L}, \mathrm{K}, \mathrm{M}, \mathrm{B}, \mathrm{F}, \mathrm{SC}$ \\
\hline P. antarctica & King George Island & Adult & $\mathrm{L}, \mathrm{K}, \mathrm{M}, \mathrm{B}, \mathrm{F}, \mathrm{SC}$ \\
\hline P. adeliae & King George Island & Adult & $\mathrm{L}, \mathrm{K}, \mathrm{M}, \mathrm{B}, \mathrm{F}, \mathrm{SC}$ \\
\hline$P$. antarctica & Deception Island & Adult & $\mathrm{L}, \mathrm{K}, \mathrm{M}, \mathrm{B}$ \\
\hline$P$. antarctica & Deception Island & Adult & $\mathrm{L}, \mathrm{K}, \mathrm{M}, \mathrm{B}, \mathrm{F}$ \\
\hline$P$. antarctica & Deception Island & Adult & $\mathrm{L}, \mathrm{K}, \mathrm{M}, \mathrm{B}, \mathrm{F}, \mathrm{SC}$ \\
\hline P. antarctica & Deception Island & Adult & $\mathrm{L}, \mathrm{K}, \mathrm{M}, \mathrm{B}, \mathrm{F}$ \\
\hline P. adeliae & Avian Island & Adult & $\mathrm{L}, \mathrm{K}, \mathrm{M}, \mathrm{B}, \mathrm{F}, \mathrm{SC}$ \\
\hline P. adeliae & Avian Island & Adult & $\mathrm{L}, \mathrm{K}, \mathrm{M}, \mathrm{F}, \mathrm{SC}$ \\
\hline P. рариа & King George Island & Juvenile & $\mathrm{L}, \mathrm{K}, \mathrm{M}, \mathrm{F}, \mathrm{SC}$ \\
\hline P. papua & King George Island & Juvenile & $\mathrm{L}, \mathrm{K}, \mathrm{M}, \mathrm{F}, \mathrm{SC}$ \\
\hline P. рариа & King George Island & Juvenile & $\mathrm{L}, \mathrm{K}, \mathrm{M}, \mathrm{F}, \mathrm{SC}$ \\
\hline P. papua & King George Island & Juvenile & $\mathrm{L}, \mathrm{K}, \mathrm{M}, \mathrm{F}, \mathrm{SC}$ \\
\hline P. adeliae & King George Island & Juvenile & $\mathrm{L}, \mathrm{K}, \mathrm{M}, \mathrm{F}$ \\
\hline
\end{tabular}

$L$ liver, $K$ kidney, $M$ muscle, $B$ bone, $F$ feather, $S C$ stomach content

during austral summers (from December to February) from 2007 to 2010 in different locations of the Antarctic Peninsula area, ranging from $62^{\circ} 15^{\prime} \mathrm{S} 58^{\circ} 37^{\prime} \mathrm{W}$ to $67^{\circ} 46^{\prime} \mathrm{S} 68^{\circ} 64^{\prime} \mathrm{W}$ (see Fig. 1). A specimen was considered as a juvenile when it has nearly finished the shedding of down feathers into adult plumage. Samples of liver $(n=17)$, kidney $(n=17)$, muscle $(n=17)$, bone $(n=10)$, feather $(n=15)$, and stomach content (composed mainly of krill) $(n=12)$ were taken by necropsies of the penguin carcasses and frozen individually in polyethylene bags.

The analytical method used in this study was that of Jerez et al. (2010) with minor modification. Before analysis, penguin tissues were rinsed with Milli-Q water, and all the samples were homogenized and dried at $75-80{ }^{\circ} \mathrm{C}$ till constant weight. Between 0.1236 and $0.4324 \mathrm{~g}$ of the material, according to availability, were subjected to microwave digestion with $\mathrm{HNO}_{3}(65 \%), \mathrm{H}_{2} \mathrm{O}_{2}(30 \%)$, and $\mathrm{H}_{2} \mathrm{O}$ (proportion 5:2:3). The elements $\mathrm{Al}, \mathrm{Cr}, \mathrm{Mn}, \mathrm{Fe}, \mathrm{Ni}, \mathrm{Cu}, \mathrm{Zn}, \mathrm{As}$, $\mathrm{Se}, \mathrm{Cd}$, and $\mathrm{Pb}$ were determined by mass spectrometry with inductively coupled plasma (ICP-MS Thermo-Optek Serio X7). All of the reagents used were Suprapur (Merck), and the water was double-distilled and deionized (Milli-Q system, Millipore, USA). The analytical precision was verified by use of blanks every five samples, initial calibration standards, and certified reference materials (DORM-2 and DOLT-2; Table 2).

According to Smith et al. (2007), values below instrumental detection limits were predicted from expected normal scores when more than $50 \%$ of all samples showed detectable levels within each data set. If not, detection limit values were assigned. 
Fig. 1 Sampling sites

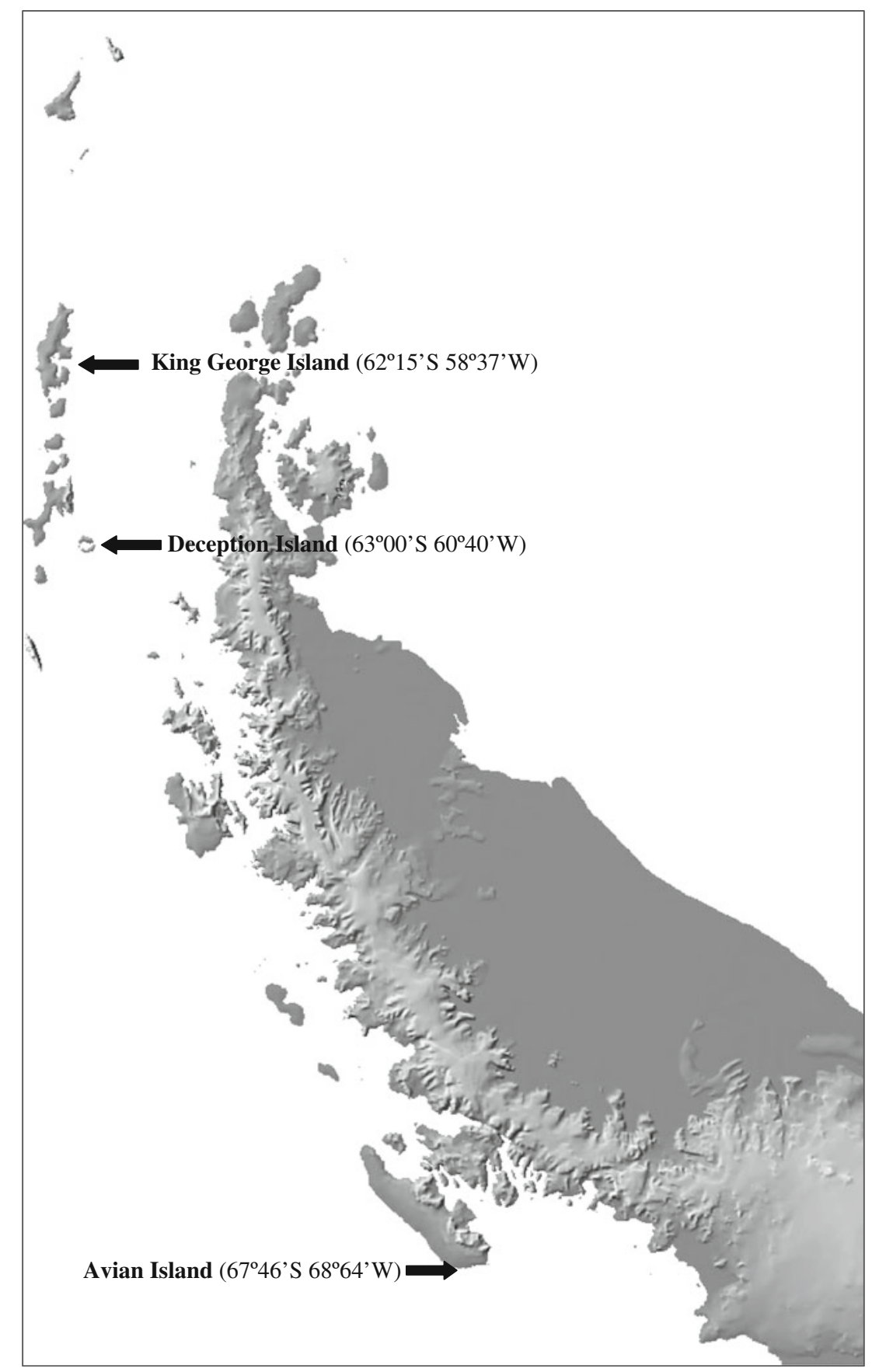

Statistical analyses were conducted using SPSS version 15.0. Non-parametric statistical methodologies were used because of the assumptions of normality and homoscedasticity were not met even after the log transformation of the data. Statistically significant differences in metal accumulation in penguin internal tissues, feathers, and stomach contents and differences in metal concentrations between juvenile and adult individuals were assessed by using Kruskal-Wallis and MannWhitney $U$ tests. Post hoc tests were carried out for KruskalWallis analyses (least significant difference between mean ranks). Spearman rank correlation coefficients were calculated between pairs of elements. A $p$ value less than 0.05 was considered to indicate statistical significance. Results are presented as mean \pm standard deviation in micrograms per gram dry weight. Small sample sizes preclude statistical analyses for inter-specific and inter-population comparisons.

\section{Results and discussion}

Different accumulation patterns were observed in penguin organs and tissues (Tables 3 and 4). Cd levels showed that 
Table 2 Detection limit values (nanograms per gram), reference material values (micrograms per gram), and percentage of recovery obtained

\begin{tabular}{llllll}
\hline Element & Detection limits & DORM-2 & \% recovery & DOLT-2 & \% recovery \\
\hline $\mathrm{Al}$ & 3.88 & $10.90 \pm 1.70$ & 80.20 & $25.20 \pm 2.40$ & 97.43 \\
$\mathrm{As}$ & 0.20 & $18.00 \pm 1.10$ & 93.44 & $16.60 \pm 1.10$ & 95.39 \\
$\mathrm{Cd}$ & 0.10 & $0.043 \pm 0.008$ & 93.02 & $20.80 \pm 0.50$ & 97.34 \\
$\mathrm{Cr}$ & 0.20 & $34.70 \pm 5.50$ & 85.63 & $0.37 \pm 0.08$ & 90.81 \\
$\mathrm{Cu}$ & 0.80 & $2.34 \pm 0.16$ & 94.36 & $25.80 \pm 1.10$ & 102.13 \\
$\mathrm{Fe}$ & 1.70 & $142.00 \pm 10.00$ & 97.84 & $1,103.00 \pm 47.00$ & 89.97 \\
$\mathrm{~Pb}$ & 0.80 & $0.065 \pm 0.007$ & 110.70 & $0.22 \pm 0.02$ & 89.15 \\
$\mathrm{Mn}$ & 0.40 & $3.66 \pm 0.34$ & 103.93 & $6.88 \pm 0.56$ & 86.44 \\
$\mathrm{Ni}$ & 0.40 & $4.64 \pm 0.26$ & 84.87 & $2.14 \pm 0.28$ & 107.00 \\
$\mathrm{Se}$ & 0.70 & $19.40 \pm 3.10$ & 93.36 & $0.20 \pm 0.02$ & 94.54 \\
$\mathrm{Zn}$ & 2.70 & $1.40 \pm 0.09$ & 85.41 & $6.06 \pm 0.49$ & 94.89 \\
\hline
\end{tabular}

this toxic metal was mainly accumulated in the kidney and liver of penguins in comparison to the rest of analyzed tissues $(p<0.0001)$, which is a common pattern previously described for several organisms (e.g., Burger 2008; Koizumi et al. 2008; Włostowski et al. 2010). The low ratio we observed between $\mathrm{Cd}$ concentrations in hepatic and renal tissues ( ratio $\mathrm{Cd}_{\text {liver/kidney }}=0.08$ ) was indicative of a chronic exposure to relatively high levels of this metal. Besides, penguins accumulated $\mathrm{Cd}$ during their life time $(\mathrm{Cd}$ levels in the kidney, muscle, and feather in adults were higher than those detected in juveniles, $p<0.05$ ), giving rise to elevated $\mathrm{Cd}$ levels in kidney of adult specimens, even above the tentative toxicity thresholds described for birds (Furness 1996; Larison et al. 2000; Rodrigue et al. 2007; Stout et al. 2002) (see Fig. 2). Our results also showed clear signs of biomagnification: $\mathrm{Cd}$ concentration in penguin kidneys was 314.43 times higher than the concentration detected in their stomach contents composed of krill, the main penguins' prey $(p<0.0001)$.

The accumulation of toxic concentrations of $\mathrm{Cd}$ can cause several adverse effects on bird health: renal tubular and testicular damage, disorder in calcium balance and skeletal integrity, reduction of food intake and growth rate, diminution in egg laying, egg shell thinning or behavior alterations, among others (Burger 2008; Furness 1996; Larison et al. 2000; Rodrigue et al. 2007). However, marine birds seem to be less vulnerable to exposure to high $\mathrm{Cd}$ levels than other wild organisms and birds (Burger 2008; Furness 1996).

Local volcanism is important in the study area (Thomson et al. 2001), and it can be an important natural source of metals such as $\mathrm{Cd}$ for organisms (Burger and Gochfeld 2004). This volcanic activity could be the responsible, at least partially, of the observed great differences on $\mathrm{Cd}$ concentration among the studied rookeries (see Tables 3 and 4). Other natural phenomena have been proposed as important $\mathrm{Cd}$ sources in Polar Regions, for example, upwelling of Cd-rich waters and algal bloom (Bargagli et al.
1996). But also anthropogenic sources at local and global scale (smelters, batteries, paints, corrosive coatings, plastic stabilizers, fertilizers, etc.) can bring about an increase of $\mathrm{Cd}$ levels in Antarctica since this metal can be long-range transported atmospherically bound to fine particles (Burger 2008; Furness 1996; McLaughlin et al. 1996).

Se was mainly accumulated in the liver and kidney, whereas $\mathrm{Zn}$ was mainly accumulated in the liver, kidney, and bone $(p<0.0001$; Tables 3 and 4$)$ as it occurs in other seabirds (Kim et al. 2009; Ribeiro et al. 2009). As in the case of Cd, Se and $\mathrm{Zn}$ levels found in several penguin internal tissues were higher than those detected in their stomach contents (4.99 and 3.97 times higher in the kidney, respectively, $p<0.0001)$. These high Se and $\mathrm{Zn}$ levels and the observed positive correlations between $\mathrm{Se}-\mathrm{Cd}$ and $\mathrm{Zn}-\mathrm{Cd}$ in penguin tissues (see Table 5 and Fig. 2) can be related to the detoxifying role that these essential elements play against $\mathrm{Cd}$ toxicity (e.g. Jerez et al. 2011; Norheim 1987): High Se and Zn levels can be protecting penguins, at least partially, against the toxic effects prompted by the exposure to elevated $\mathrm{Cd}$ levels.

We also observed differences among adult and juvenile specimens in the kidney, muscle, and feather $(p<0.05$, Tables 3 and 4) that point out that Se was accumulated in penguins during their life cycle. Although Se is an essential element and can play a protection role against $\mathrm{Cd}$ toxicity, Se accumulation can also be causing adverse effects on penguins' health, such as behavioral abnormalities or reproductive deficits (Eisler 1985; Heinz 1996; Ohlendorf 1989). We observed that $47.06 \%$ of the studied specimens showed higher Se levels in liver than the toxicity threshold established by Lemley (1993) for aquatic birds $\left(10 \mu \mathrm{gg}^{-1} \mathrm{~d}\right.$.w.), although the interaction of Se with other trace elements may modify its toxicity (Heinz 1996). These high Se levels detected in penguins could be related to the high Se levels detected in their stomach contents; the $58.33 \%$ of these samples contained Se concentrations potentially toxic for penguins (more than $3 \mu \mathrm{gg}^{-1}$ d.w. in preys is considered as toxic for aquatic birds, Lemley 1993). 


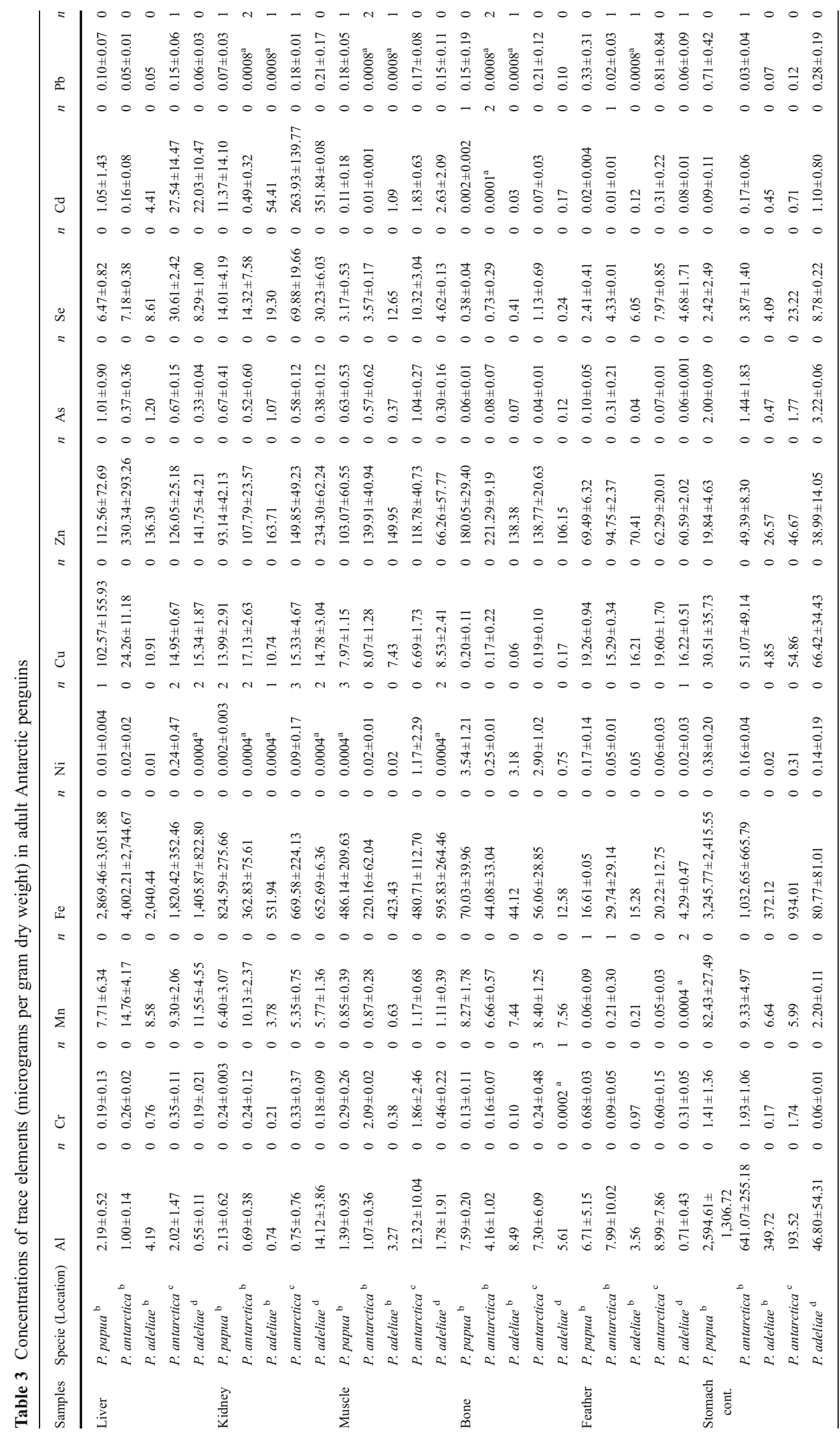

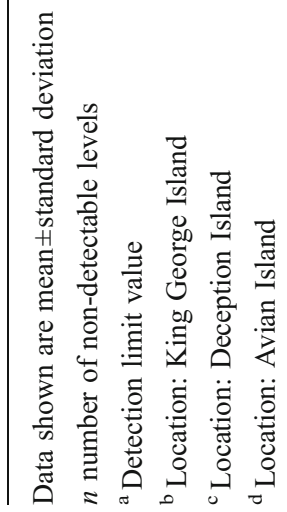




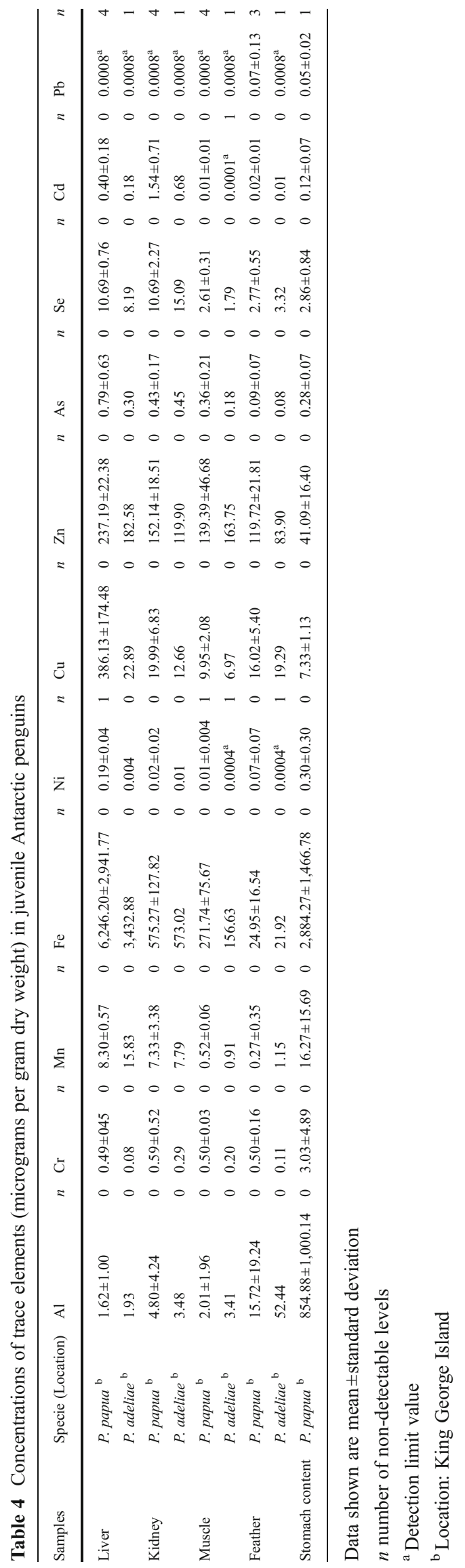

Unlike Se, we observed that $\mathrm{Zn}$ levels in liver and feather were higher in juveniles than in adult penguins $(p<0.05)$. This pattern was also observed for $\mathrm{Fe}$ and $\mathrm{Cu}$ in penguins' liver $(p<0.05)$ and can be related to the major requirements of these metals in young organisms (Mas 1993).

We found the highest Mn levels in the liver, kidney, and bone ( $p<0.0001$; Tables 3 and 4 ) although our results suggest that $\mathrm{Mn}$ does not increase with age in penguins as occurs in other seabirds (Barbieri et al. 2010). In the last years, a potential increase of the environmental levels of $\mathrm{Mn}$ has been suggested to be due to the use of this metal as additive to combustibles (e.g. Burger and Gochfeld 2000; Mispagel et al., 2003). In this way, we found Mn levels in our samples slightly higher (between 0.87 and 2.13 times in hepatic tissue) than those detected by Honda et al. (1986) and Szefer et al. (1993b) two decades ago in tissues of adult Antarctic penguins (6.80$8.80 \mathrm{\mu gg}^{-1}$ d.w.) and similar to those detected more recently in penguin chicks by Smichowski et al. (2006) (10.00, 9.40, and $1.50 \mu \mathrm{gg}^{-1}$ d.w. in the liver, kidney, and muscle, respectively). Mn levels detected in our samples of Antarctic penguins were similar or slightly lower than those detected in liver, muscle or feather samples of Arctic seabirds (ranging from 7.13 to $15.00 \mathrm{\mu gg}^{-1}$ d.w. in liver, from 1.84 to $2.56 \mathrm{\mu gg}^{-1}$ d.w. in muscle and from 0.75 to $1.10 \mathrm{\mu gg}^{-1}$ d.w. in feather, see Burger et al. 2008 and Campbell et al. 2005) but sharply lower than Mn levels recently detected in feathers of adult seabirds coming from more industrialized and populated areas such as the Brazilian coasts (11.36 $\mathrm{\mu gg}^{-1}$ d.w.; Barbieri et al. 2010). Although the comparison of metal levels among different species and populations of seabirds must be taken with caution (Jerez et al. 2011) and data are still scarce in Antarctica, our results seem to point out a certain increase of Mn pollution in Antarctica.

We observed differences in $\mathrm{Pb}$ concentrations in soft tissues (the liver, kidney, and muscle) and feathers between juvenile and adult penguins $(p<0.0001$ and $p<$ 0.05 , respectively), which show that penguins accumulated $\mathrm{Pb}$ during their life time (see Tables 3 and 4). This accumulation occurred despite $\mathrm{Pb}$ can be partially eliminated during the process of feather growth (Jerez et al. 2011). The affinity of $\mathrm{Pb}$ to calcium-formations such as feathers brings about the accumulation of this toxic and non-essential metal in feathers during their growth and allows the elimination of an important proportion of $\mathrm{Pb}$ from the birds' body. In accordance with this, in juvenile specimens, we found detectable levels of $\mathrm{Pb}$ only in feather samples while internal tissues showed non-detectable levels (see Table 4). With respect to adult specimens, we also found the maximum level of $\mathrm{Pb}$ in feather samples (1.74 $\mu \mathrm{gg}^{-1}$ d.w.) (see Table 3$)$. So penguin feathers seem to be useful samples for the study of $\mathrm{Pb}$ exposure in these organisms, as well as for 
monitoring the presence of this metal in the Antarctic environment.

$\mathrm{Pb}$ monitoring is often used to evaluate the presence of anthropogenic pollution in the environment (e.g., Sun and Xie, 2001), since this metal is not metabolically regulated for organisms (Gochfeld et al. 1996) and is emitted by several human activities. Some of these activities are currently carried out in Antarctica or have been carried out in the past (fuel combustion, waste incineration, sewage disposal, paint or accidental oil spills, among others; see Bargagli 2008 and dos Santos et al. 2005). Besides local activities, global environmental pollution can also increase $\mathrm{Pb}$ concentrations in Antarctica, and this heavy metal may find its way into the food web, bioaccumulate, and be passed along the food chain to penguins (Sun and Xie 2001). We detected the maximum $\mathrm{Pb}$ levels in penguin feathers from King George and Deception Islands (0.55 and $1.74 \mu \mathrm{gg}^{-1}$ d.w., respectively) where a relevant human presence exists. These results were consistent with those previously found (Jerez et al. 2011). These relatively high $\mathrm{Pb}$ levels detected in King George and Deception Islands were even comparable with $\mathrm{Pb}$ levels detected in seabirds' feathers from the Northern Hemisphere (Burger et al. 2008; Ribeiro et al. 2009) and seem to be influenced by anthropogenic sources of pollution. These results are in agreement with Sun and Xie (2001) who proved that $\mathrm{Pb}$ concentrations in Antarctic penguin droppings have increased during the last 200 years, especially in the last 50 years, as a consequence of the increasing global pollution and local pressure.

$\mathrm{Ni}$ tended to accumulate mainly in penguin bones $(p<$ 0.0001 , Table 3) where this metal reached levels significantly higher than those detected in penguins' stomach contents $(p<0.0001)$. Ni could also have been accumulated in penguin bodies during their life cycle since the concentration in muscle tissue was higher in adults than in juveniles $(p<$ 0.05; see Tables 3 and 4). These results are indicative of the existence of $\mathrm{Ni}$ accumulation and magnification. $\mathrm{Ni}$ is an essential metal that is naturally distributed in the environment (Eisler 1998), although anthropogenic sources can increase natural Ni levels (e.g., mining, chemical industry, fuel combustion, waste incineration, sewage disposal, paint or accidental oil spills; ATSDR 2005). The limited availability of samples did not allow analyzing geographical differences in $\mathrm{Ni}$ concentrations in this study, but as in the case of $\mathrm{Pb}$, we found the highest $\mathrm{Ni}$ concentrations in samples from King George and Deception Islands (bones4.40 and $3.82{\mu g g^{-1}}$ d.w., respectively). These results suggest that anthropogenic sources could be responsible, at least partially, of $\mathrm{Ni}$ accumulation in penguins. Ni showed a high affinity to bone samples, and this kind of samples can be easily collected for Ni monitoring in the Antarctic environment since penguin bones are really abundant in rookery areas.
The highest Fe levels were found in soft tissues $(p<$ 0.0001; Tables 3 and 4), especially in liver which has been described as storing tissue of Fe inside the organisms (Mas 1993). Fe levels were higher in hepatic tissues of penguins than in their stomach contents $(p<0.05)$.

Regarding differences among populations, Fe and Al levels seemed to be higher in stomach contents and feathers of penguins from King George and Deception Islands in comparison to penguins from Avian Island (see Table 3): $\mathrm{Al}$ and $\mathrm{Fe}$ in feathers were between 5.01-12.66 and 3.56-6.93 times higher, respectively, and $\mathrm{Al}$ and $\mathrm{Fe}$ in stomach contents were between 4.14-55.44 and 4.61-40.19 times higher, respectively. Unfortunately, these differences could not be statistically checked due to the sample shortage. The abundance of $\mathrm{Al}$ and Fe in samples from King George and Deception Islands could be related to the abundance of these metals in bioavailable forms in the sediments of these areas (Almendros et al. 1997; Deheyn et al. 2005; dos Santos et al. 2005; Rey et al. 1995).

The highest $\mathrm{Cu}$ levels were found in the liver, kidney, and feathers $(p<0.0001$; Tables 3 and 4$)$. $\mathrm{Cu}$ levels in liver of penguins were similar to those detected in other seabirds from the Northern Hemisphere (ranging from 19.10 to $92.50 \mathrm{\mu gg}^{-1}$ d.w., see Lucia et al. 2010 and Ribeiro et al. 2009). Penguin feathers showed $\mathrm{Cu}$ levels even higher than seabird feathers from China ( $4 \mu \mathrm{gg}^{-1}$ d.w., see Liu et al. 2006). These high $\mathrm{Cu}$ levels detected in penguins seem to be directly connected with the high $\mathrm{Cu}$ amounts detected in Antarctic krill in this study (maximum level, $90.76 \mu^{-1} g^{-1}$ d.w.) and previously (41.30 $\mu \mathrm{g}$ $\mathrm{g}^{-1}$ d.w.; Nygard et al. 2001). However, temporal tends on $\mathrm{Cu}$ levels in Antarctica should be checked in the future since human activities (oil spills, sewage, or solid waste) can contribute to increase $\mathrm{Cu}$ levels in coastal marine ecosystems (Eisler 1981).

The highest levels of As were found in soft tissues $(p<$ 0.0001 ; Tables 3 and 4) where this metal is rapidly distributed and retained when goes into the body (ATSDR 2007). Our results on As levels in soft tissues were similar to those detected in chick penguins from King George Island (0.50, 0.55 , and $0.82 \mathrm{\mu gg}^{-1} \mathrm{~d} . \mathrm{w}$. in the liver, kidney, and muscle, respectively, see Smichowski et al. 2006) and to those detected in Arctic seabirds (from 0.17 to $0.32 \mu \mathrm{gg}^{-1} \mathrm{~d}$.w. in feather samples, see Burger et al. 2008). Seabirds from other regions of the world showed a wide range of As levels (from 0.22 to $5.62 \mathrm{\mu gg}^{-1} \mathrm{~d}$.w. in liver; Lucia et al. 2010; Ribeiro et al. 2009) which could be related to differences in their diets (Kubota et al. 2001). In accordance with Braune and Noble (2009), As levels in our samples were lower than $3 \mu \mathrm{gg}^{-1} \mathrm{~d}$.w. (see Table 3), which are usual levels in living organisms. The As values reported in this study were very low in comparison to values known to produce toxic effects, such as endocrine disruption, in seabirds $\left(>50 \mathrm{\mu gg}^{-1}\right.$ d.w.; Neff 1997). 
Fig. 2 Normal, elevated, and toxic $\mathrm{Cd}$ levels in penguin renal tissues and correlations with $\mathrm{Se}$ and $\mathrm{Zn}$ levels. Data are shown as micrograms per gram dry weight. Toxic threshold taken from Furness (1996)
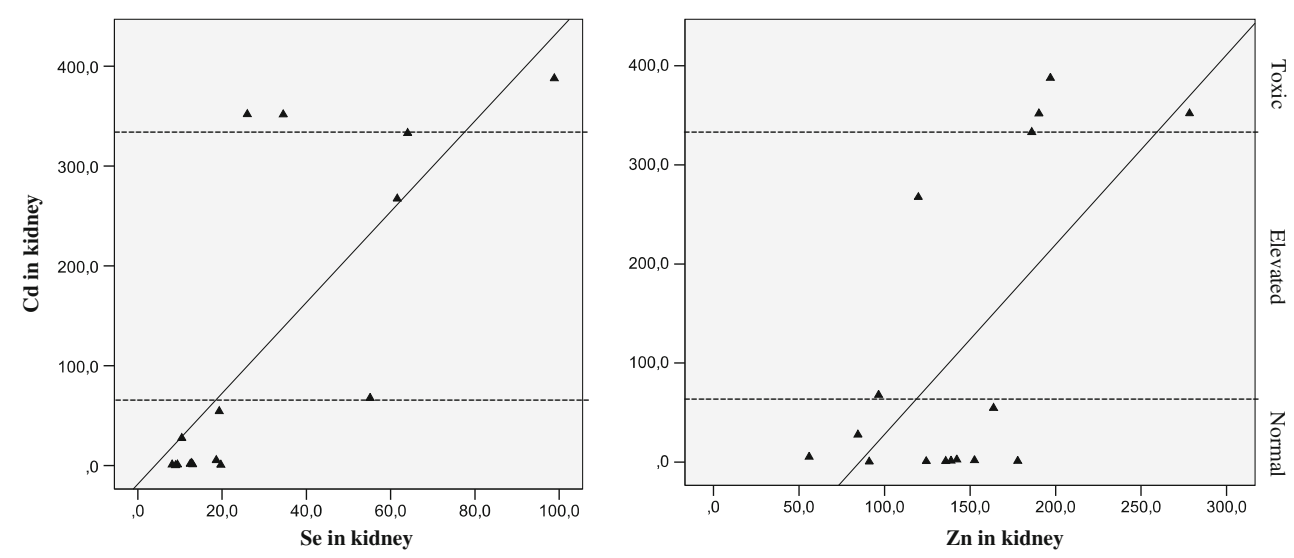

Cr did not show a clear pattern of accumulation in any specific tissue, although we found the highest $\mathrm{Cr}$ levels in muscle tissue of specimens from King George and Deception Islands (maximum levels -2.10 and $5.52{\mu g^{-1}}^{-1}$ d.w., respectively). Unlike Szefer et al. (1993b) that found non-detectable Cr levels $\left(<0.03 \mu \mathrm{gg}^{-1}\right.$ d.w.) in the majority of the analyzed tissues of Antarctic penguins, we found detectable levels in the $95.45 \%$ of them. These results seem to indicate than an increase on Cr levels can be occurring in Antarctica, although this possibility should be taken with caution since data on levels of this metal in penguins are still scarce and could be influenced by diet differences among populations. This possible increase could be related with the increase of human presence in some Antarctic areas such as King George or Deception Islands since $\mathrm{Cr}$ is associated with several human activities and oil contamination (Alam and Sadiq 1993; Caccia et al. 2003). The majority of the studied specimens of penguins showed $\mathrm{Cr}$ levels one order of magnitude lower than those detected in soft tissues of seabirds from the Northern Hemisphere, although feathers of penguins from King George and Deception Islands showed $\mathrm{Cr}$ levels close to those detected in feathers of Arctic seabirds (from 1.81 to 8.22 and from 0.95 to $2.03 \mu \mathrm{g}$ $\mathrm{g}^{-1}$ d.w. in soft tissues and feathers, respectively, see Burger et al. 2008 and Ribeiro et al. 2009).

$\mathrm{Al}, \mathrm{Cr}, \mathrm{Mn}, \mathrm{Cu}$, and As did not show signs of magnification or accumulation during the penguins' life time.

The $72.97 \%$ of the observed correlations between pairs of elements were positive (Table 5). The predominance of this kind of correlations among the studied elements may suggest common uptake and storage pathways or similar regulation and detoxification processes in penguins as occur in other seabirds (Mendes et al. 2008; Nam et al. 2005; Perez-Lopez et al. 2006; Ribeiro et al. 2009).

Specifically in feathers, we found six different positive correlations between pairs of elements, suggesting that penguin feathers accumulate metals during their growth due to the existence of a high blood flow. This accumulation in feathers allows the elimination of partial contents of toxic metals from the organism.

In soft tissues, we also found several positive correlations between essential elements such as $\mathrm{Fe}-\mathrm{Zn}, \mathrm{Fe}-\mathrm{Se}, \mathrm{Fe}-\mathrm{Cu}$, $\mathrm{Fe}-\mathrm{Ni}$, and $\mathrm{Cu}-\mathrm{Zn}$ that can indicate the existence of similar metabolic regulations for these pairs of elements (Ribeiro et al. 2009). We found other positive correlations between pairs of toxic elements known to be related with the presence of contaminant activities ( $\mathrm{Cr}-\mathrm{Mn}, \mathrm{Cr}-\mathrm{Pb}, \mathrm{Mn}-\mathrm{As}$, $\mathrm{Mn}-\mathrm{Pb}$, and $\mathrm{Cd}-\mathrm{Pb}$ ) suggesting the existence of common anthropogenic sources of these metals in the study area.

We also found negative correlations such as the observed between $\mathrm{Pb}-\mathrm{Zn}, \mathrm{Pb}-\mathrm{Cu}$, and $\mathrm{Pb}-\mathrm{Fe}$ in liver. These results may be related to the ability of $\mathrm{Pb}$ to supplant polyvalent cations and use their transport mechanisms (Ballatori 2002), hindering the transport and accumulation of essential elements in the studied specimens.

\section{Conclusions}

The studied penguins, especially those specimens collected in Deception and Avian Islands, were chronically exposed to high $\mathrm{Cd}$ levels, and this metal was mainly accumulated in renal tissue. The study of $\mathrm{Cd}$ levels in penguin tissues and their stomach contents (composed mainly of krill) showed signs of biomagnification for this metal in the Antarctic food web. Several specimens of penguins showed elevated $\mathrm{Cd}$ levels in the kidney, even above the toxicity threshold proposed for birds. We also found high Se and $\mathrm{Zn}$ levels in penguin tissues which could be playing a protection role against the toxic effects of the elevated exposure to $\mathrm{Cd}$. Se even reached toxic concentrations in hepatic tissue. The obtained results indicated that a slight increase in $\mathrm{Mn}$ and $\mathrm{Cr}$ levels in Antarctica could exist and could be related with a major human presence, use of combustibles, and oil contamination.

Feathers seem to be an important elimination way of the absorbed $\mathrm{Pb}$ in penguins. In spite of that, $\mathrm{Pb}$ was accumulated during the penguins' life cycle. Ni was also accumulated in 


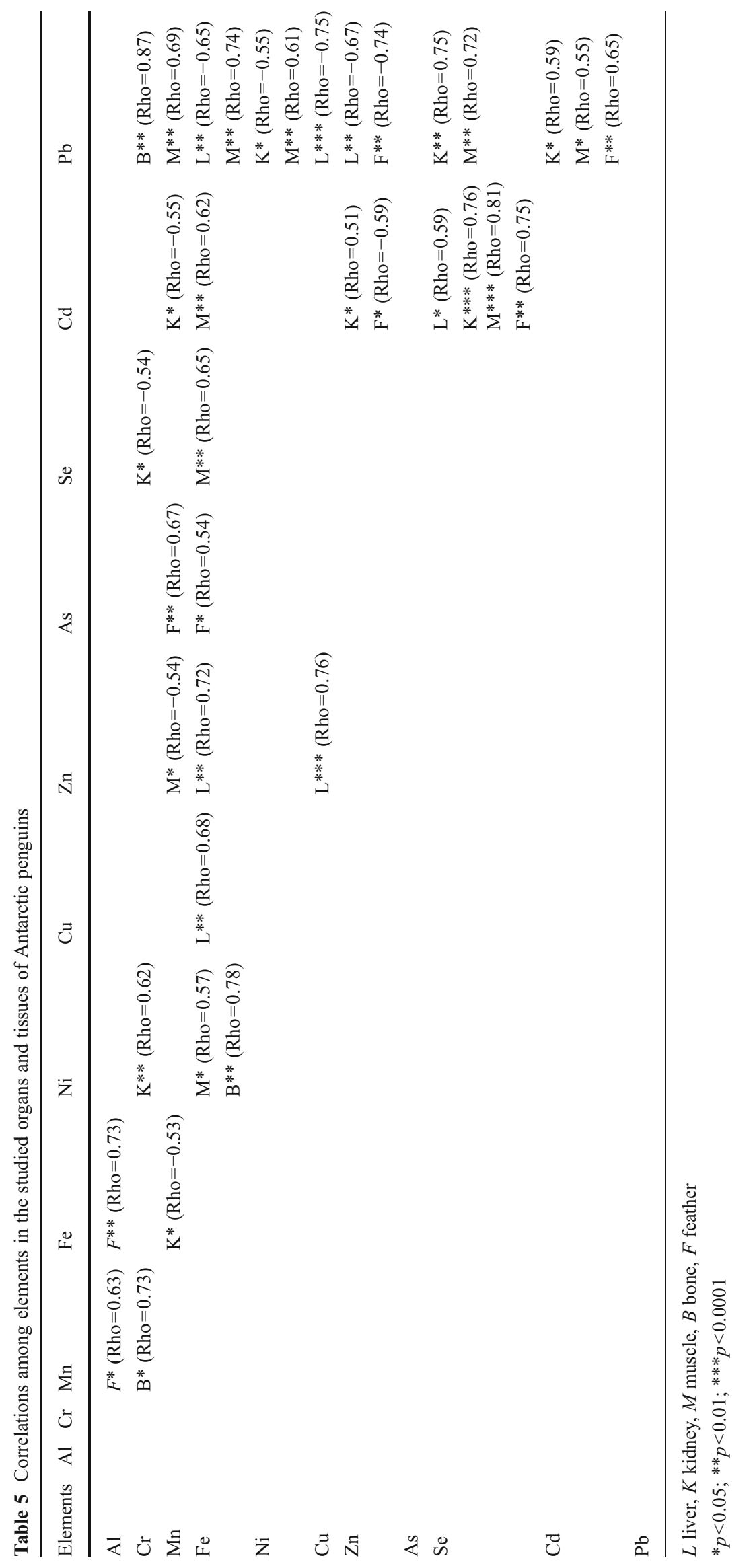


penguins, mainly in bones. Feathers and bones could be useful samples non-invasively and easily collected for monitoring $\mathrm{Pb}$ and $\mathrm{Ni}$, respectively, in the Antarctic ecosystems. The highest levels of $\mathrm{Pb}$ and $\mathrm{Ni}$ in this study were detected in specimens from areas where a major human presence exists (King George and Deception Islands), and this fact suggests that these metals, at least partially, came from anthropogenic sources.

High $\mathrm{Cu}$ levels were detected in penguins probably related to the high $\mathrm{Cu}$ levels present in their main prey, Antarctic krill. Signs of bioaccumulation or biomagnification phenomena were not observed for $\mathrm{Cu}$ and neither for $\mathrm{Al}, \mathrm{Cr}$, $\mathrm{Mn}$, and As in the studied specimens.

Finally, we found a wide number of positive correlations between pairs of elements. These results indicate in general that similar uptake and storage pathways existed for them, as well as similar internal processes of regulation and/or detoxification. And particularly for metals known to be related with anthropogenic contamination $(\mathrm{Cr}, \mathrm{Mn}, \mathrm{As}, \mathrm{Cd}, \mathrm{Pb})$, these results suggest that common anthropogenic sources existed for them in the study area. These sources seem to be increasing the presence of toxic metals in Antarctic penguins.

Acknowledgments We thank the Spanish polar ship Las Palmas, the Spanish polar base "Gabriel de Castilla," the Argentinean polar base "Carlini," the Instituto Antártico Argentino and the Maritime Technology Unit (CSIC) for providing logistic support. We also thank the Scientific Instrumentation Service (University of Murcia) and the Technological Instrumentation Service (Technical University of Cartagena) for their analytical support. Permissions to work in the study area were given by the Spanish Polar Committee. This study has been funded by the Spanish Ministry of Science and Innovation CGL20401348, POL2006-05175, and CGL2007-60369. This study is a contribution to the International Polar Year project 172 BirdHealth and to Pinguclim project. Finally, the authors gratefully acknowledge the feedback provided by anonymous referees.

\section{References}

Alam IA, Sadiq M (1993) Metal concentrations in Antarctic sediments samples collected during the Trans-Antarctica 1990 expedition. Mar Pollut Bull 26:523-527

Almendros J, Ibáñez JM, Alguacil G, Del Pezzo E, Ortiz R (1997) Array tracking of the volcanic tremor source at Deception Island, Antarctica. Geophys Res Lett 24:3069-3072

Ancora S, Volpi V, Olmastroni S, Focardi S, Leonzio C (2002) Assumption and elimination of trace elements in Adélie penguins from Antarctica: a preliminary study. Mar Environ Res 54:341-344

Andrade S, Poblet A, Scagliola M, Vodopivez C, Curtosi A, Pucci A et al (2001) Distribution of heavy metals in surface sediments from an Antarctic marine ecosystem. Environ Monit Assess 66:147-158

ATSDR (2005) Toxicological profile for Nickel. Agency for Toxic Substances and Disease Registry, US Department of Health and Human Services, Public Health Service, Atlanta

ATSDR (2007) Toxicological profile for Arsenic. U.S. Agency for Toxic Substances and Disease Registry, US Department of Health and Human Services, Public Health Service, Atlanta

Ballatori N (2002) Transport of toxic metals by molecular mimicry. Environ Health Perspect 110:689-694
Barbieri E, de Andrade PE, Filippini A, Souza dos Santos I, Borges CA (2010) Assessment of trace metal concentration in feathers of seabird (Larus dominicanus) sampled in the Florianópolis, SC, Brazilian coast. Environ Monit Assess 169:631-638

Bargagli R (2008) Environmental contamination in Antarctic ecosystems. Sci Total Environ 400:212-226

Bargagli R, Nelli L, Ancora S, Focardi S (1996) Elevated cadmium accumulation in marine organisms from Terra Nova Bay (Antarctica). Polar Biol 16:513-520

Bargagli R, Monaci F, Sánchez-Hernández JC, Cateni D (1998) Biomagnification of mercury in an Antarctic marine coastal food web. Mar Ecol Prog Ser 169:65-76

Braune B, Noble D (2009) Environmental contaminants in Canadian shorebirds. Environ Monit Assess 148:185-204

Burger J (2008) Assessment and management of risk to wildlife from cadmium. Sci Total Environ 389:37-45

Burger J, Gochfeld M (2000) Metal levels in feathers of 12 species of seabirds from Midway Atoll in the northern Pacific Ocean. Sci Total Environ 257:37-52

Burger J, Gochfeld M (2004) Marine birds as sentinels of environmental pollution. Ecohealth 1:263-274

Burger J, Gochfeld M, Sullivan K, Irons D, McKnight A (2008) Arsenic, cadmium, chromium, lead, manganese, mercury, and selenium in feathers of black-legged Kittiwake (Rissa tridactyla) and Black Oystercatcher (Haematopus bachmani) from Prince William Sound, Alaska. Sci Total Environ 398:20-25

Caccia VG, Millero FJ, Palanques A (2003) The distribution of trace metals in Florida Bay sediments. Mar Pollut Bull 46:1420-1433

Campbell L, Norstrom R, Hobson K, Muir D, Backus S, Fisk A (2005) Mercury and other trace elements in a pelagic Arctic marine food web (Northwater Polynya, Baffin Bay). Sci Total Environ 351352:247-263

Claridge GGC, Campbell IB, Powell HKJ, Amin ZH, Balks M (1995) Heavy metal contamination in some soils of the McMurdo Sound region, Antarctica. Antarct Sci 7:9-14

Curtosi A, Pelletier E, Vodopivez C, St Louis R, Mac Cormack WP (2010) Presence and distribution of persistent toxic substances in sediments and marine organisms of Potter Cove, Antarctica. Arch Environ Contam Toxicol 59:582-592

De Moreno JEA, Gerpe MS, Moreno VJ, Vodopivez C (1997) Heavy metals in Antarctic organisms. Polar Biol 17:131-140

Deheyn DD, Gendreau P, Baldwin RJ, Latz MI (2005) Evidence for enhanced bioavailability of trace elements in the marine ecosystem of Deception Island, a volcano in Antarctica. Mar Environ Res 60:1-33

Dos Santos IR, Silva-Filho EV, Schaefer CE, Albuquerque-Filho MR, Campos LS (2005) Heavy metal contamination in coastal sediments and soils near the Brazilian Antarctic Station, King George Island. Mar Pollut Bull 50:185-194

Eisler R (1981) Trace metal concentrations in marine organisms. Pergamon, New York

Eisler R (1985) Selenium hazards to fish, wildlife and invertebrates: a synoptic review. U.S. Fish and Wildlife Service, Biological Report 85 (1.5), Washington, DC

Eisler R (1998) Nickel hazards to fish, wildlife, and invertebrates: a synoptic review. Geological Survey, Biological Resources Division, Biological Science Report, Washington, DC

Furness RW (1996) Cadmium in birds. In: Beyer WN, Heinz GH, Redmon-Norwood AW (eds) Environmental contaminants in wildlife: interpreting tissue concentrations. Lewis, Boca Raton, pp 389-404

Gochfeld M, Belant JL, Shukla T, Benson T, Burger J (1996) Heavy metals in laughing gulls: gender, age and tissue differences. Environ Toxicol Chem 15:2275-2283 
Heinz GH (1996) Selenium in birds. In: Beyer WN, Heinz GH, Redmon-Norwood AW (eds) Environmental contaminants in wildlife: interpreting tissue concentrations. Lewis, Boca Raton, pp 447-458

Honda K, Yamamoto Y, Hidaka H, Tatsukawa R (1986) Heavy metal accumulation in Adélie penguin, Pygoscelis adeliae, and their variations with the reproductive process. Mem Natl Inst Polar Res 40:443-453

IAATO (2010) 2009-2010 tourism summary. International Association of Antarctica Tour Operators Web. http://www.iaato.org/tourism stats.html. Accessed 22 Dec 2011

Jerez S, Motas M, Cánovas RA, Talavera J, Almela RM, Bayón A (2010) Accumulation and tissue distribution of heavy metals and essential elements in loggerhead turtles (Caretta caretta) from Spanish Mediterranean coastline of Murcia. Chemosphere 78:256-264

Jerez S, Motas M, Palacios MJ, Valera F, Cuervo JJ, Barbosa A (2011) Concentration of trace elements in feathers of three Antarctic penguins: geographical and interspecific differences. Environ Pollut 159:2412-2419

Kim J, Shin JR, Koo TH (2009) Heavy metal distribution in some wild birds from Korea. Arch Environ Contam Toxicol 56:317-324

Koizumi N, Murata K, Hayashi C, Nishio H, Goji J (2008) High cadmium accumulation among humans and primates: comparison across various mammalian species - a study from Japan. Biol Trace Elem Res 121:205-214

Kubota R, Kunito T, Tanabe S (2001) Arsenic accumulation in the liver tissue of marine mammals. Environ Pollut 115:303-312

Kureishy TW, Gupta RS, Mesquita A, Sanzgiry S (1993) Heavy metals in some parts of Antarctica and the southern Indian Ocean. Mar Pollut Bull 26:651-652

Larison JR, Likens GE, Fitzpatrick JW, Crock JG (2000) Cadmium toxicity among wildlife in the Colorado Rocky Mountains. Nature 406:181-183

Lemley AD (1993) Guidelines for evaluating selenium data form aquatic monitoring and assessment studies. Environ Monit Assess 28:83-100

Liu X, Zhao S, Sun L, Yin X, Xie Z, Honghao L et al (2006) P and trace metal contents in biomaterials, soils, sediments and plants in colony of red-footed booby (Sula sula) in the Dongdao Island of South China Sea. Chemosphere 65:707-715

Lucia M, André JM, Gontier K, Diot N, Veiga J, Davail S (2010) Trace element concentrations (mercury, cadmium, copper, zinc, lead, aluminium, nickel, arsenic, and selenium) in some aquatic birds of the Southwest Atlantic Coast of France. Arch Environ Contam Toxicol 58:844-853

Mas A (1993) Elementos esenciales. In: Mas A, Azcue JM (eds) Metales en Sistemas Biológicos. Promociones y Publicaciones Universitarias, Barcelona, pp 105-142 (in Spanish)

McLaughlin MJ, Tiler KG, Naidu R, Stevens DP (1996) Review: the behaviour and environmental impact of contaminants in fertilizers. Aust J Soil Res 34:1-54

Mendes P, Eira C, Torres J, Soares AMVM, Melo P, Vingada J (2008) Toxic element concentration in the Atlantic gannet Morus bassanus (Pelecaniformes, Sulidae) in Portugal. Arch Environ Contam Toxicol 55:503-509

Metcheva R, Yurukova L, Teodorovac S, Nikolova E (2006) The penguin feathers as bioindicator of Antarctica environmental state. Sci Total Environ 362:259-265

Mispagel C, Turoczy N, Stagnitti F (2003) Copper, manganese, lead and zinc concentrations on Eucalyptus sp. leaves in a small coastal town. Bull Environ Contam Toxicol 71:617-624

Nam DH, Anan Y, Ikemoto T, Okabe Y, Kim EY, Subramanian A et al (2005) Specific accumulation of 20 trace elements in great cormorants (Phalacrocorax carbo) from Japan. Environ Pollut 134:503-514

Neff JM (1997) Ecotoxicology of arsenic in the marine environment. Environ Toxicol Chem 16:917-927
Norheim G (1987) Levels and interactions of heavy metals in seabirds from Svalbard and the Antarctic. Environ Pollut 47:83-94

Nygard T, Lie E, Rov N, Steinnes E (2001) Metal dynamics in an Antarctic food chain. Mar Pollut Bull 42:598-602

Ohlendorf HM (1989) Bioaccumulation and effects of selenium in wildlife. In: Jacobs LW (ed) Selenium in agriculture and the environment. SSSA special publication no. 23. American Society of Agronomy and Soil Science Society of America, Madison, pp 133-177

Perez-Lopez MP, Cid F, Oropesa L, Fidalgo LE, Beceiro AL, Soler F (2006) Heavy metal and arsenic content in seabirds affected by the Prestige oil spill on the Galician coast (NW Spain). Sci Total Environ 359:209-220

Poblet A, Andrade S, Scagliola M, Vodopivez C, Curtosi A, Pucci A et al (1997) The use of epilithic Antarctic lichens (Usnea aurantiacoatra and $U$. antartica) to determine deposition patterns of heavy metals in the Shetland Islands, Antarctica. Sci Total Environ 207:187-194

Rey J, Somoza L, Martínez-Frías J (1995) Tectonic, volcanic and hydrothermal event sequence on Deception Island (Antarctica). Geo-Mar Lett 15:1-8

Ribeiro AR, Eira C, Torres J, Mendes P, Miquel J, Soares AMVM et al (2009) Toxic element concentrations in the razorbill Alca torda (Charadriiformes, Alcidae) in Portugal. Arch Environ Contam Toxicol 56:588-595

Rodrigue J, Champoux L, Leclair D, Duchesne JF (2007) Cadmium concentrations in tissues of willow ptarmigan (Lagopus lagopus) and rock ptarmigan (Lagopus muta) in Nunavik, Northern Québec. Environ Pollut 147:642-647

Sánchez-Hernández JC (2000) Trace element contamination in Antarctic ecosystems. Rev Environ Contam Toxicol 166:82-127

Scheifler R, Gauthier-Clerc M, Le Bohec C, Crini N, Coeurdassier M, Badot PM et al (2005) Mercury concentrations in king penguin (Aptenodytes patagonicus) feathers at Crozet Islands (subAntarctic): temporal trend between 1966-1974 and 2000-2001. Environ Toxicol Chem 24:125-128

Smichowski P, Vodopivez C, Muñoz-Olivas R, Gutierrez AM (2006) Monitoring trace elements in selected organs of Antarctic penguin (Pygoscelis adeliae) by plasma-based techniques. Microchem $\mathrm{J}$ $82: 1-7$

Smith P, Cobb G, Godard-Codding C, Hoff D, McMurry S, Rainwater $\mathrm{T}$ et al (2007) Contaminant exposure in terrestrial vertebrates. Environ Pollut 150:41-64

Stewart FM, Phillips RA, Catry P, Furness RW (1997) Influence of species, age and diet on mercury concentrations in Shetland seabirds. Mar Ecol Prog Ser 151:237-244

Stout JH, Trust KA, Cochrane JK, Suydam RS, Quakenbush LT (2002) Environmental contaminants in four eider species from Alaska and arctic Russia. Environ Pollut 119:215-226

Sun L, Xie Z (2001) Changes in lead concentration in Antarctic penguin droppings during the past 3,000 years. Environ Geol 40:1205-1208

Szefer P, Czarnowski W, Pempkowiak J, Holm E (1993a) Mercury and major essential elements in seals, penguins, and other representative fauna of the Antarctic. Arch Environ Contam Toxicol 25:422-427

Szefer P, Pempkowiak J, Skwarzec B, Bojanowski R, Holm E (1993b) Concentration of selected metals in penguins and other representative fauna of the Antarctica. Sci Total Environ 138:281-288

homson MRA, Pankhurst RJ, Clarkson PD (2001) The Antarctic Peninsula - a late Mesozoic-Cenozoic arc (review). In: Oliver RL, James PR, Jago JB (eds) Antarctic Earth Science. Cambridge University Press, Cambridge, pp 289 294 
Vodopivez C, Curtosi A (1998) Trace metals in some invertebrates, fishes and birds from Potter Cove. In: Wiencke C, Ferreyra G, Arntz W, Rinaldi C (eds) The Potter Cove coastal ecosystem, Antarctica. Ber Polarforsch, Bremerhaven, pp 296-303

Walsh PM (1990) The use of seabirds as monitors of heavy metals in the marine environment. In: Furness RW, Rainbow PS (eds)
Heavy metals in the marine environment. CRC, Boca Raton, pp 183-204

Włostowski T, Dmowski K, Bonda-Ostaszewska E (2010) Cadmium accumulation, metallothionein and glutathione levels, and histopathological changes in the kidneys and liver of magpie (Pica pica) from a zinc smelter area. Ecotoxicology 19:1066-1073 